\title{
Sistem Informasi Pencarian Tambal Ban Terdekat Berbasis Location Based Service ( Studi Kasus Kota Malang )
}

\author{
Handitya Setya Budi ${ }^{1)}$, Hari Lugis Purwanto ${ }^{2)}$, Rini Agustina ${ }^{3)}$ \\ 1, 2, 3) Program Studi Sistem Informasi, Universitas Kanjuruhan Malang, Indonesia \\ Email Penulis: nagrem25@ gmail.com ${ }^{1)}$, hari_lugis.unikama.ac.id ${ }^{2)}$, riniagustina@ unikama.ac.id ${ }^{3)}$
}

\begin{abstract}
Based on the Central Bureau of Statistics, the number of motorized vehicles in Indonesia in 2015 reached 121.39 million units [2] The number of motorized vehicles is expected to continue to increase from year to year. This will be directly proportional to the number of people who are damaged when driving, such as leaking tires or breaking tires. However, the large number of tire patches in Indonesia is not balanced by providing sufficient information about tire patches. Therefore it is necessary to have a mobile device that can help the user in finding the closest tire patch. Android itself now provides various platforms, one of which is the LBS feature. LBS can also be defined as information services by utilizing technology to find out the position of something. Applying LBS in this time is very appropriate because the output results obtained are very accurate and precise so they can optimize the search for the nearest tire patch. Based on the results of the user acceptance test, it can be concluded that the system provides the expected results with a percentage of $87.78 \%$.
\end{abstract}

Keywords - Android, Location Based Service; Search for Tire Patches

\begin{abstract}
Abstrak. Berdasarkan Data Badan Pusat Statistik jumlah kendaraan bermotor di Indonesia pada tahun 2015 mencapai 121,39 juta unit [2]. Jumlah kendaraan bermotor ini diperkirakan akan terus meningkat dari tahun ke tahun. Hal ini akan berbanding lurus dengan banyaknya orang yang mengalami kerusakan ketika berkendara, seperti ban bocor atau pecah ban. Namun, banyaknya tambal ban di Indonesia tidak diimbangi dengan pemberian informasi yang cukup tentang tempat tambal ban. Maka dari itu perlu adanya perangkat bergerak yang dapat membantu user dalam mencari tambal ban terdekat. Android sendiri sekarang sudah menyediakan berbagai platform salah satunya fitur LBS. LBS dapat didefinisikan pula sebagai layanan informasi dengan memanfaatkan teknologi untuk mengetahui posisi sesuatu. Menerapkan LBS dalam kali ini sangatlah tepat dikarenakan hasil output yang didapatkan sangatlah akurat dan tepat sehingga dapat mengotimalkan dalam mencari tambal ban terdekat. Berdasarkan hasil uji user acceptance test, dapat diambil kesimpulan yaitu sistem memberikan hasil yang diharapkan dengan persentase $87,78 \%$.
\end{abstract}

Kata Kunci - Android, Location Based Service; Pencarian Tambal Ban

\section{PENDAHULUAN}

\section{A. Latar Belakang}

Dengan semakin berkembangnya teknologi mobile saat ini, berdampak pada akses informasi yang semakin mudah dan cepat, bahkan diimbangi dengan harga yang semakin terjangkau membuat pertumbuhan pengguna smartphone meningkat sangat pesat. Perangkat GPS yang sudah dibenamkan kedalam smartphone semakin mempermudah perkembangan teknologi Location Based Service menjadi lebih luas dan semakin inovatif. Menurut Tempo.co, dalam pembuka acara Google I/O yang diselenggarakan di Moscone Center West, San Fransisco, Google mengumumkan bahwa hingga saat ini tercatat ada 900 juta perangkat Android yang telah diaktifkan. Sundar Pichai sebagai Vice President Android dan Chrome sempat mengatakan bahwa ini menjadi tahun terbaik bagi para pengembang Android.

Berdasarkan Data Badan Pusat Statistik jumlah kendaraan bermotor di Indonesia pada tahun 2015 mencapai 121,39 juta unit [2]. Jumlah kendaraan bermotor ini diperkirakan akan terus meningkat dari tahun ke tahun. Hal ini akan berbanding lurus dengan banyaknya orang yang mengalami kerusakan ketika berkendara, seperti ban bocor atau pecah ban. Namun, banyaknya tempat tambal ban di Indonesia tidak diimbangi dengan pemberian informasi yang cukup untuk mengetahui tempat tambal ban yang terdekat. Keterbatasan akses informasi inilah yang menyebabkan sebagian besar masyarakat, khususnya para pengendara kendaraan bermotor merasa kesulitan untuk menemukan lokasi tempat tambal ban ketika kendaraan mereka mengalami permasalahan diatas, sebagai contoh kasus ada seorang pengendara sedang mengalami kendala ban bocor di 
sekitar kampus kanjuruhan, pengendara tersebut bingung akan menambal dimana dikarenakan lokasi tambal ban yang dia ketahui cukup jauh padahal di sekitar dia banyak lokasi tambal ban yang jaraknya lebih dekat.

\section{B. Batasan Masalah}

Asumsi dan keterbatasan dalam penelitian ini adalah sebagai berikut :

1. Aplikasi pencarian tambal ban hanya bisa dijalankan pada sistem operasi android

2. Aplikasi hanya bisa dijalankan di android versi 4.4 keatas

3. Ruang lingkup terbatas hanya di Kota Malang

4. Hanya dapat menangani kendala ban bocor dan ban pecah.

5. Diperuntukkan bagi pengguna kendaraan roda dua dan roda empat

\section{Tujuan Penelitian}

Tujuan dari dibuatnya aplikasi ini adalah sebagai berikut :

1. Mempermudah pengguna dalam menentukan tambal ban terdekat

2. Mempermudah pengguna dalam menemukan jalur terdekat.

\section{Referensi Penelitian}

LBS sendiri sudah pernah dilakukan penelitian, diantaranya seperti penelitian Slameto [3], yang berjudul "Penerapan Location Based Services Untuk Pembuatan Aplikasi Pencarian Tambal Ban Terdekat Berbasis Android", menyimpulkan bahwa dengan menggunakan Google API yang digunakan untuk mengakses peta Google maka jangkauan area aplikasi seluas jangkauan peta Google. Penelitian juga pernah dilakukan diterapkan oleh Ardiansyah dkk [1], yang berjudul "Layanan Informasi Lokasi Event Menggunakan LBS Berbasis Jquery Mobile", menyimpulkan bahwa Hasil penilitian ini adalah diperoleh sistem layanan informasi lokasi event dengan metode LBS berbasis mobile yang dapat memberikan kemudahan pengaksesan detail lokasi event calon peserta yang berminat terhadap event yang ingin dikunjungi.

\section{METODE}

\section{A. Prototyping}

Berdasarkan tujuan penelitian yang diuraikan pada Bab I, maka penelitian ini menggunakan metode penelitian dan pengembangan atau R\&D (Research and Development). R\&D merupakan metode penelitian yang digunakan untuk menghasilkan produk tertentu[4]. Produk yang dihasilkan adalah sistem informasi pencarian tambal ban berbasis android. Model untuk menghasilkan suatu perangkat lunak sebagai process model. Jenis process model yang digunakan adalah model prototyping. Adapun contoh Model Prototyping dapat terlihat dalam gambar 2.1 sebagai berikut:

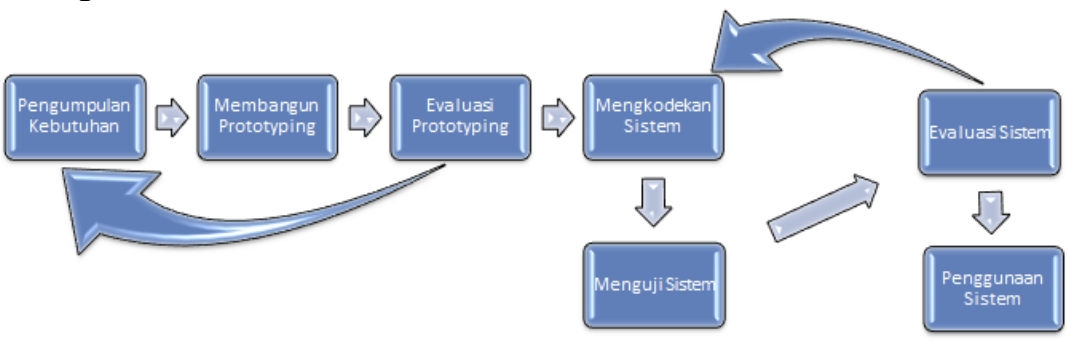

Gambar 2.1 Model Prototyping

Pengumpulan kebutuhan

Pada tahap ini peneliti melakukan observasi dan wawancara dengan mengajukan pertanyaan mengenai kebutuhan dan fungsi yang akan dibutuhkan. Berdasarkan hasil observasi di lapangan ( kecamatan sukun ), jumlah data tambal ban yang didapat sementara berjumlah 39 tambal ban dan berdasarkan hasil wawancara dapat 
disimpulkan bahwa user pengguna mengalami kesulitan dalam menemukan tambal ban yang terdekat dan didapatkan kebutuhan fungsional dan non fungsional untuk memenuhi kebutuhan sistem yang akan dibuat.

Membangun prototyping

Setelah kebutuhan fungsional dan non fungsional didapatkan, peneliti mulai membangun sebuah prototyping berbasis gui. Disini penulis menggunakan android studio sebagai sarana dalam pembuatan prototyping dikarenakan di android studio terdapat tampilan xml yang memudahkan user pengguna dalam memahami design yang akan dibuat.

Evaluasi protoptyping

Setelah prototype sudah jadi, penulis melakukan ujicoba kepada 9 orang, yang diantaranya 6 user pengguna dan 3 pemilik tambal ban. Disini penulis mendemonstrasikan prototype dan menjelasan secara singkat tentang sistem yang akan dibuat. Setelah demonstrasi penulis mengevaluasi dengan menyebarkan kuisioner ke- 9 orang tersebut.

\section{Mengkodekan sistem}

Setelah melihat hasil kuisioner dan hasil yang didapat cukup memuaskan. Penulis memulai mengembangkan prototype yang sudah jadi, dari memasukkan fungsinya dan login ke hak akses masing-masing. Disini penulis menggunakan android studio dan notepad++ sebagai editor, bahasa PHP sebagai bahasa server dan JAVA untuk bahasa program di aplikasi androidnya.

Menguji system

Dalam tahap ini dilakukan penulis melakukan uji blackbox dalam tiap masing-masing menu. Untuk menu admin yang menguji adalah penulis sendiri, filter tambal ban dan order tambal ban yang menguji user pengguna sedangkan terima tambal ban yang menguji adalah pemilik tambal ban

Evaluasi system

Dalam tahap ini penulis melakukan UAT untuk mengetahui tingkat kepuasan user pengguna dan pemilik tambal ban dalam menggunakan aplikasi sistem informasi pencarian tambal ban berbasis android.

Menggunakan system

Disini penulis melakukan pemeliharaan seperti maintenance dan melakukan update apabila ada masukkan dari pengguna aplikasi pencarian tambal ban berbasis android.

\section{HASIL DAN PEMBAHASAN}

\section{A. Analisis Kebutuhan}

Analisis kebutuhan ini peneliti melakukan observasi dan wawancara dengan mengajukan pertanyaan mengenai kebutuhan dan fungsi yang akan dibutuhkan dalam system pencarian tambal ban. Berdasarkan hasil observasi di lapangan, jumlah data tambal ban yang didapat sementara berjumlah 39 tambal ban dan berdasarkan hasil wawancara maka dapat dibuatlah rancangan sistem yang dapat terlihat pada gambar 3.1 sebagai berikut : 


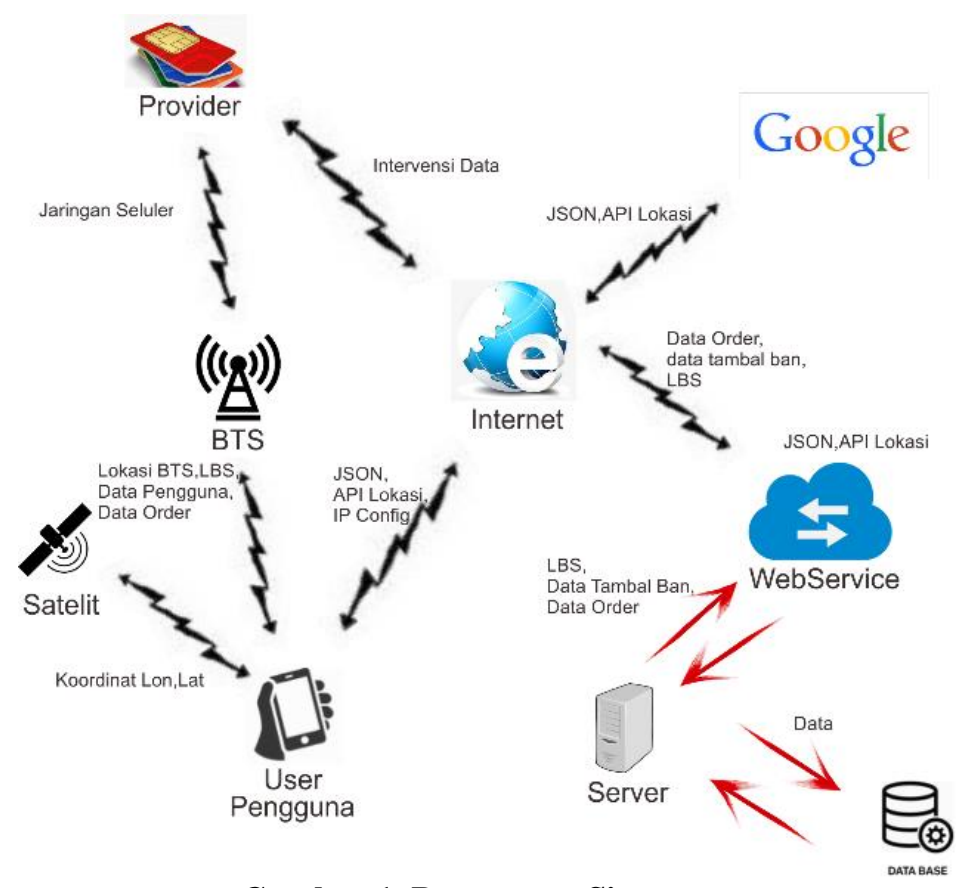

Gambar 1. Rancangan Sistem

Penjelasan Rancangan Sistem adalah sebagai berikut:

Saat User Pengguna pertama kali menyalakan hp, menghidupkan GPS dan data seluler (paket data), maka secara otomatis user akan menerima sinyal dari satelit berupa lon dan lat dan dari provider berupa sinyal lokasi BTS, langkah selanjutnya perangkat mengirim ke Google dan mendapatkan json berupa API LBS, selanjutnya sistem secara otomatis akan mengirim ke server melalui web service dan melakukan perhitungan untuk menentukan lokasi tambal ban terdekat dari sekian tamban ban yang ada. Langkah terakhir sistem akan menampilkan ke user pengguna berupa list tambal ban dari yang terdekat sampai terjauh.

\section{B. Desain Produk}

Berikut merupakan gambar use case diagram utama pencarian tambal ban dapat dilihat dalam gambar 3.2 sebagai berikut :

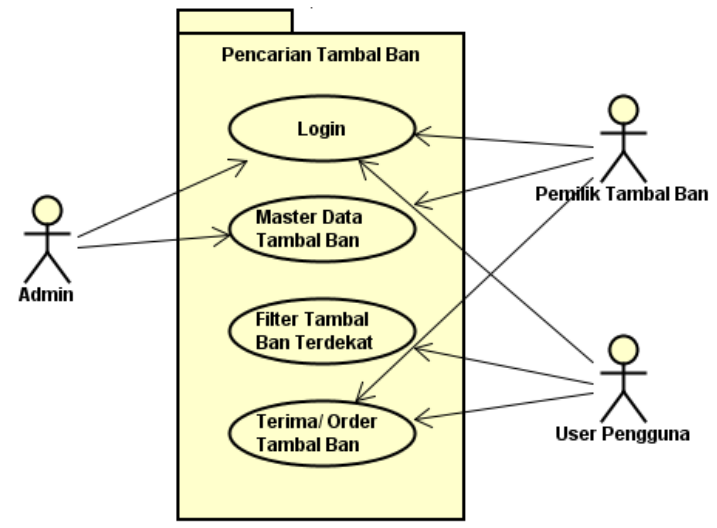

Gambar 2. Use Case Diagram Utama

Penjelasan use case diagram utama adalah sebagai berikut:

1.Login digunakan untuk membedakan dan memberikan hak akses pada tiap masing-masing user 2.Master data tambal ban digunakan untuk memonitoring data tambal ban

3.Filter Tambal Ban terdekat digunakan untuk mencari tambal ban terdekat dari lokasi user saat ini

4.Terima/Order tambal ban terdekat digunakan untuk transaksi pemnggilan pemilik tambal ban 


\section{Pemrograman}

Pada tahap proses pemrograman dilakukan pembuatan kode program sesuai hasil tahapan desain produk. Tahapan pemrograman mengimlementasikan hasil rancangan ke dalam baris kode dan tampilan sistem yang berjalan sesuai dengan fungsinya

Scripting memanggil API LBS

Berikut merupakan script pemanggilan API dapat dilihat pada gambar 3.3:

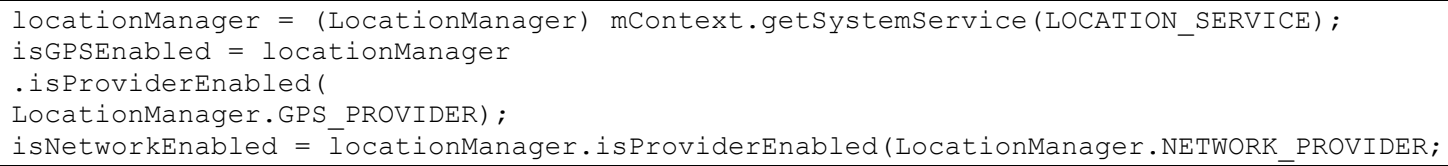

\section{Gambar 3. Script Pemanggilan API}

Scripting Filterimg Tambal Ban

Berikut merupakan script sorting dapat dilihat pada gambar 3.4:

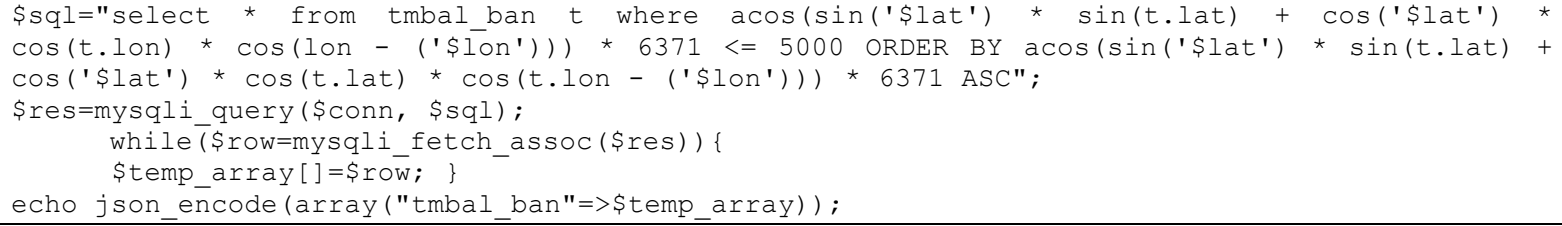

\section{Gambar 4. Script Sorting}

\section{Pengujian}

Setelah pemrograman selesai kemudian dilakukan pengujian sistem dengan blackbox testing. Pengujian dilakukan dengan membuktikan bahwa semua objek dalam sistem dapat berjalan sesuai fungsi yang ditentukan. Pengujian ini dilakukan dengan menguji semua fungsi. Hasil dari pengujian sistem blackbox testing dapat dilihat pada tabel 3 .

Tabel 3. Uji Black Box

\begin{tabular}{|c|c|c|c|c|c|}
\hline No & $\begin{array}{c}\text { Fungsi yang } \\
\text { Diuji }\end{array}$ & $\begin{array}{r}\text { Skenario } \\
\text { Pengujian }\end{array}$ & $\begin{array}{c}\text { Hasil yang } \\
\text { Diharapkan }\end{array}$ & Hasil Pengujian & Keteran gan \\
\hline UCBL & $\begin{array}{l}\text { Mastering data } \\
\text { user }\end{array}$ & $\begin{array}{l}\text { Tambah data } \\
\text { user }\end{array}$ & $\begin{array}{l}\text { Sistem sukses } \\
\text { insert,update,delete } \\
\text { data }\end{array}$ & $\begin{array}{lr}\text { Sistem } & \text { sukses } \\
\text { menyimpan data ke } \\
\text { database }\end{array}$ & Valid \\
\hline UCBD & Login & $\begin{array}{l}\text { Memasukkan } \\
\text { username dan } \\
\text { password }\end{array}$ & Masuk menu utama & $\begin{array}{l}\text { Sukses Login dan } \\
\text { masuk ke menu utama }\end{array}$ & Valid \\
\hline UCBMP & $\begin{array}{l}\text { Filter Tambal } \\
\text { Ban }\end{array}$ & $\begin{array}{l}\text { Sistem dapat } \\
\text { melakukan } \\
\text { sorting tambal } \\
\text { ban }\end{array}$ & $\begin{array}{l}\text { Sorting tambal ban } \\
\text { dari terdekat } \\
\text { sampai terjauh }\end{array}$ & $\begin{array}{lr}\text { Sistem } & \text { menampilkan } \\
\text { otomatis } & \text { tambal ban } \\
\text { terdekat } & \text { sampai } \\
\text { terjauh } & \\
\end{array}$ & Valid \\
\hline UCBMW & $\begin{array}{l}\text { Order Tambal } \\
\text { Ban }\end{array}$ & $\begin{array}{l}\text { User pengguna } \\
\text { menekan tombol } \\
\text { order }\end{array}$ & $\begin{array}{l}\text { Sistem akan } \\
\text { menampilkan menu } \\
\text { history }\end{array}$ & \begin{tabular}{ll} 
Sistem menampilkan & \multicolumn{2}{c}{ mistory bila } \\
menu hu \\
berhasil dan akan \\
tetap di menu order \\
bila gagal
\end{tabular} & Valid \\
\hline UCBMH & Terima Order & $\begin{array}{l}\text { menekan tombol } \\
\text { terima order }\end{array}$ & $\begin{array}{l}\text { Sistem akan } \\
\text { menampilkan menu } \\
\text { history }\end{array}$ & $\begin{array}{l}\text { Sistem menampilkan } \\
\text { menu history bila } \\
\text { berhasil }\end{array}$ & Valid \\
\hline
\end{tabular}

\section{E. Implementasi}


Berikut merupakan tampilan halaman login admin yang dapat dilihat pada gambar 3.5 sebagai berikut:

\section{Login}

Silahkan masukkan username dan password anda

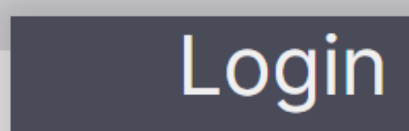

Username

admin

Password

co...॰

Submit

\section{Gambar 5. Halaman Login Admin}

Berikut merupakan tampilan halaman mastering user yang dapat dilihat pada gambar 3.6 sebagai berikut:

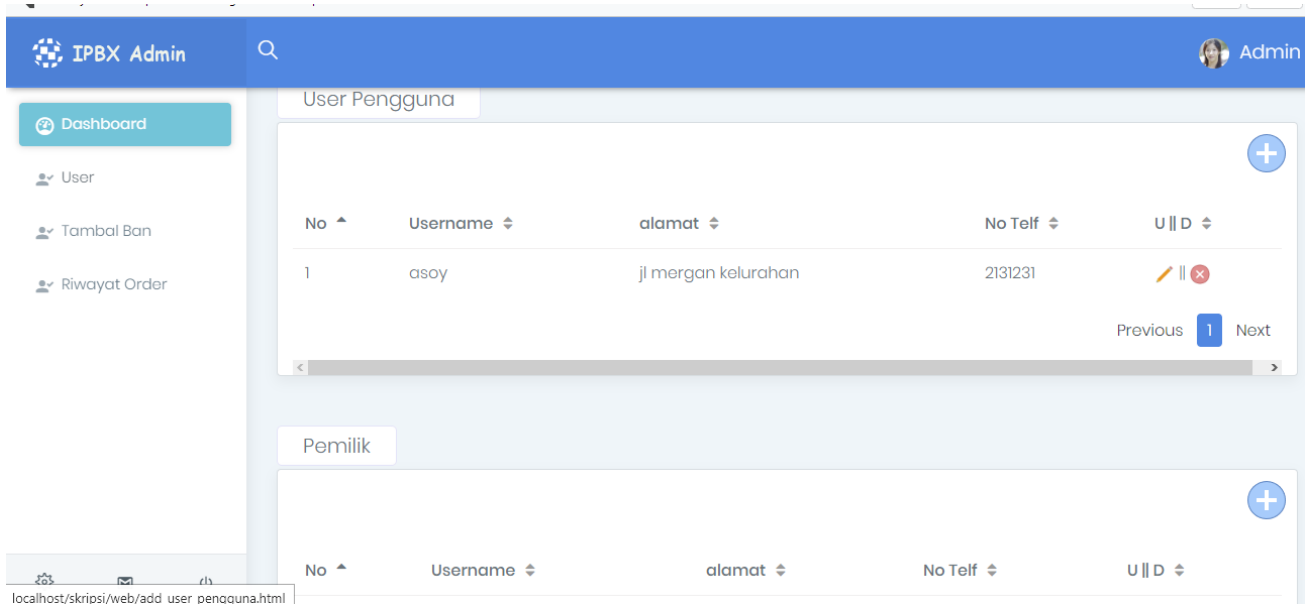

\section{Gambar 6. Halaman Mastering User}

Berikut merupakan tampilan halaman mastering data tambal ban yang dapat dilihat pada gambar 3.7 sebagai berikut:

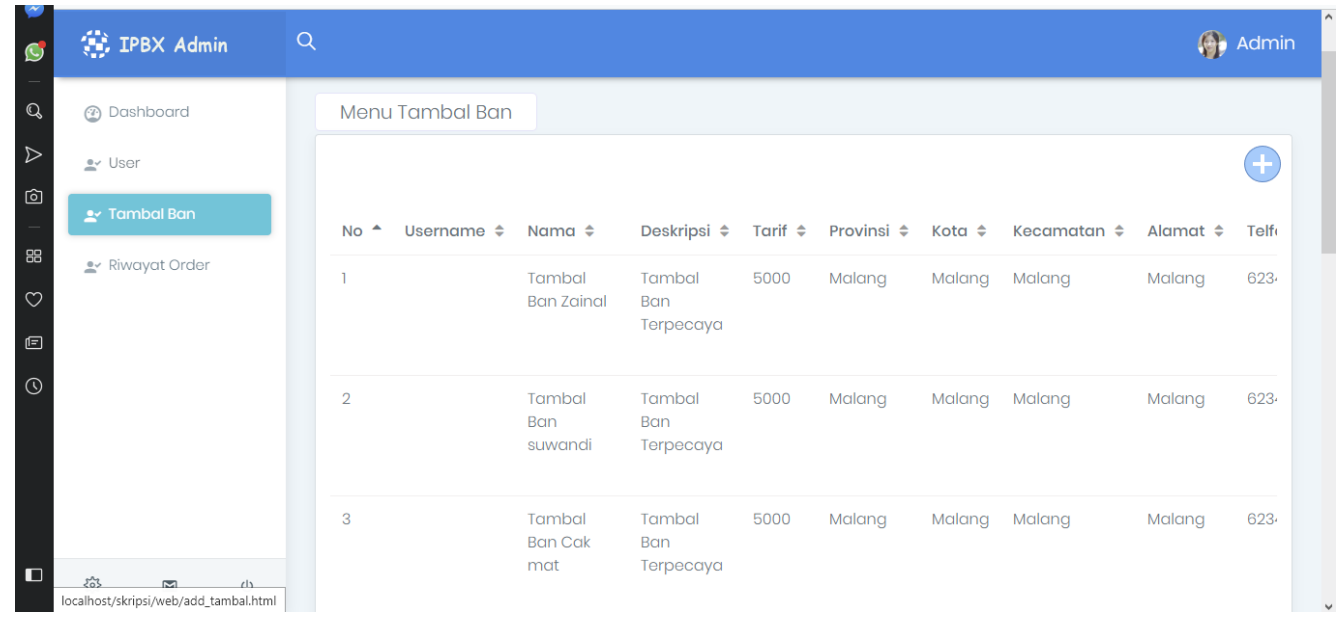




\section{Gambar 7. Halaman Master Data}

Berikut merupakan tampilan halaman filter tambal ban yang dapat dilihat pada gambar 3.8 sebagai berikut:

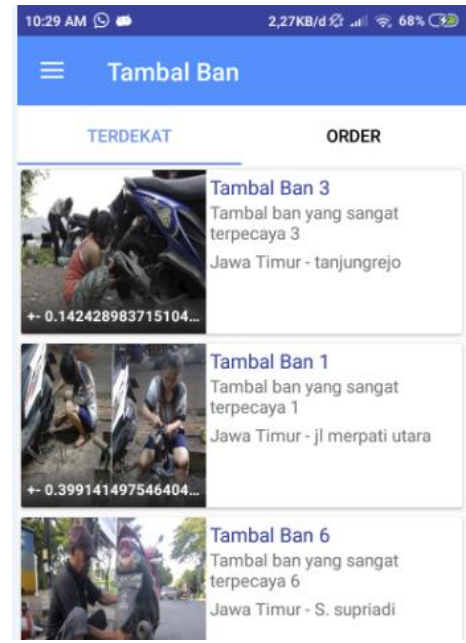

Gambar 8. Halaman filter tambal ban

Berikut merupakan tampilan halaman order tambal ban yang dapat dilihat pada gambar 3.9 sebagai berikut:

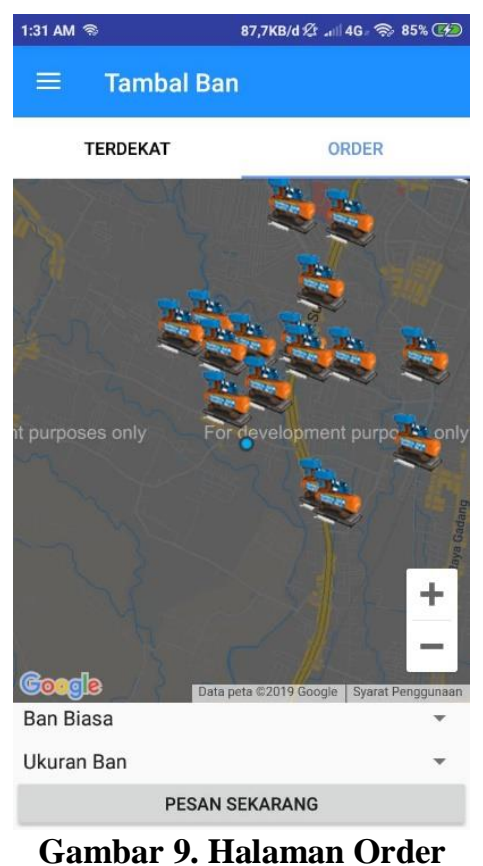

\section{KESIMPULAN}

Berdasarkan hasil penelitian dan user acceptance test yang telah dilakukan, penulis dapat menarik kesimpulan antara lain:

1. Sistem yang dikembangkan menggunakan model prototype dapat membantu user dalam mencari tambal ban terdekat berdasarkan lokasi user saat itu dan membantu pemilik dalam mempromosikan usahanya

2. Sistem dapat membantu user memilih tambal ban terdekat serta dapat menemukan jarak tempuh terdekat

\section{UCAPAN TERIMA KASIH}

Ucapan terimakasih sebesar-besarnya saya ucapkan kepada teman-teman "coding bahagia" yang telah membantu saya dan menyemangati saya. Kepada kedua orangtua saya yang selalu senantiasa memberikan dukungan baik moril maupun materil serta do'a yang tiada henti-hentinya kepada saya. Serta kepada Bapak M. 
Asni Fitrian selaku Kepala Bumdes dan Mas M. As'ari Fuddin selaku staff Bumdes Desa Slorok yang telah mengijinkan dan membantu saya untuk melakukan kegiatan penlitian di Bumdes Desa Slorok. Serta banyak ucapan terimakasih kepada bapak Yusriel dan bapak Wiwin selaku dosen pembimbing yang telah membantu dan membimbing dalam proses penulisan dan penelitian ini. Tidak lupa kepada Rektor Universitas Kanjuruhan Malang Bapak Dr. Pieter Sahertain, M.Si., dan Dekan Fakultas Sains dan Teknologi Dr. I Ketut Suastika, M.Si., serta paraa pembantu dan staff Fakultas Sains dan Teknologi (FST) serta Kaprodi Sistem Infromasi Yoyok Seby Dwanoko, S.Kom, M.Kom., beserta seluruh staffnya saya mengucapkan banyak-banyak terimakasih.

\section{REFERENSI}

[1] Ardiansyah, dkk. 2016, Layanan Informasi Lokasi Event Menggunakan LBS Berbasis Jquery Mobile. Yogyakarta : Universitas Ahmad Dahlan.

[2] BPS, 2017. Jumlah Kendaraan Bermotor Berdasarkan Plat Nomor di Kota Malang 2015-2016. https://malang kota.bps.go.id/statictable/2017/07/21/601/ jumlah-kendaraan-bermotor-berd asarkanplat-nomor-di-kota-malang-2 015-2016.html

[3] Slameto, 2015, Penerapan Location Based Services Uuntuk Pembuatan Aplikasi Pencarian Tambal Ban Berbasis Android, Yogyakarta : STMIK AMIKOM Yogyakarta

[4] Sugiyono, 2013. Metode Penelitian Kuantitatif, Kualitatif, dan R\&D. Bandung: Alfabeta. Halaman 297 